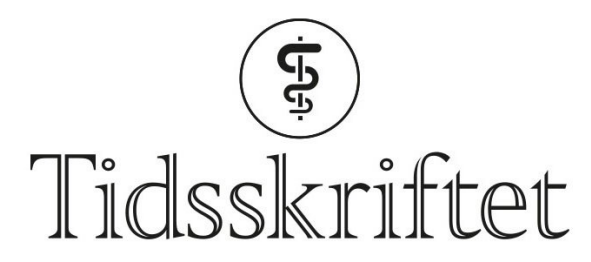

DEN NORSKE LEGEFORENING

\title{
Kraftige legger ved en sjelden tilstand
}

MEDISINEN I BILDER

\section{KRISTIN ØRSTAVIK}

E-post:krorstav@ous-hf.no

Seksjon for sjeldne nevromuskulære tilstander

Oslo universitetssykehus

Kristin Ørstavik er dr.med., spesialist i nevrologi og i klinisk nevrofysiologi, overlege og seksjonsleder. Forfatteren har fylt ut ICMJE-skjemaet og oppgir ingen interessekonflikter.

\section{EVA KIRKHUS}

Avdeling for radiologi

Klinikk for radiologi og nukleærmedisin

Oslo universitetssykehus

Eva Kirkhus ph.d., spesialist i radiologi og overlege.

Forfatteren har fylt ut ICMJE-skjemaet og oppgir ingen interessekonflikter.

\section{MARIELLE HOVLAND}

Nevrologisk avdeling

Oslo universitetssykehus

Marielle Hovland er spesialist i nevrologi og overlege.

Forfatteren har fylt ut ICMJE-skjemaet og oppgir ingen interessekonflikter.

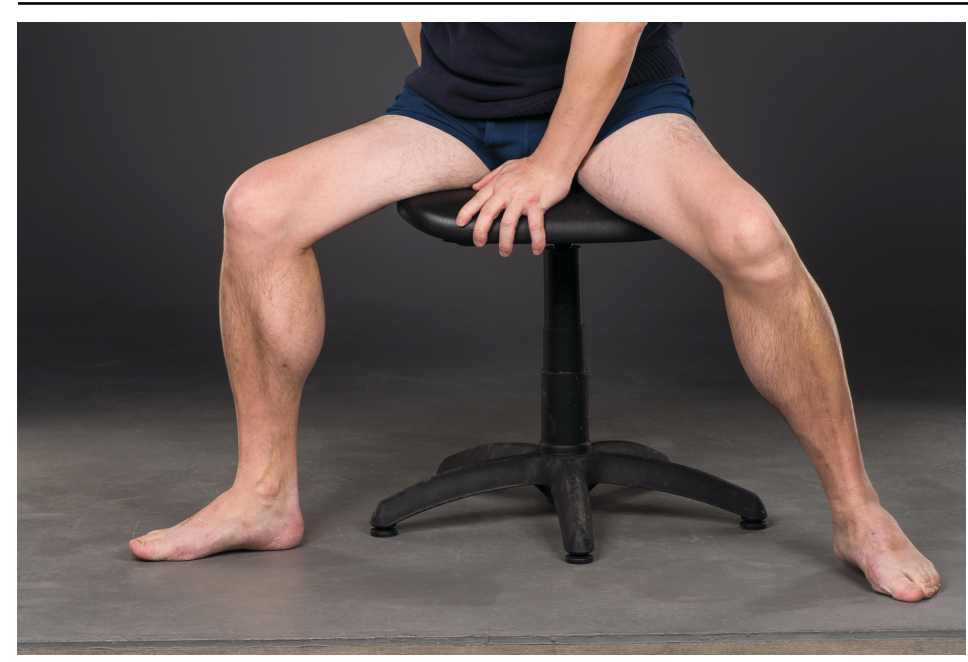

Bildet viser kraftige leggmuskler hos en pasient med spinal muskelatrofi (SMA), en recessivt arvelig motornevronsykdom, som debuterte i voksen alder (SMA type 4). Pasienten fikk problemer med balanse og svakhet proksimalt etter tenårene. Klinisk unders $\emptyset$ kelse sammen med genetisk test som viste at han var homozygot for delesjon av ekson 7 og $8 \mathrm{i}$ SMN1-genet, bekreftet diagnosen. Magnetresonansunders $ø$ kelse av leggmusklene viste pseudohypertrofi med kraftige muskelbuker, men med $ø$ kt fettinfiltrasjon, spesielt i soleusmusklene. 
Både pseudohypertrofi og hypertrofi av leggmuskler har ved noen få anledninger blitt beskrevet ved spinal muskelatrofi $(1,2)$. Pasienten er nå middelaldrende, og bildet demonstrerer at han har kraftige legger samt betydelig atrofi av lårmuskler. Han må bruke hendene for å komme seg opp fra sittende stilling (Gowers tegn)(3). I motsetning til mer alvorlige former for spinal muskelatrofi er det ingen påvirkning av livslengde ved type 4 .

Hypertrofi og pseudohypertrofi av leggmuskler er kliniske tegn ved en rekke sykdommer, også arvelige nevromuskulære tilstander (1). Leggmusklene fremstår som velutviklet sammenlignet med lårmusklene. Ved pseudohypertrofi skyldes dette at mye av muskulaturen erstattes med fett, mens det ved hypertrofi er økning i størrelsen av muskelcellene (1). Det er særlig ved dystrofinopatiene at dette er beskrevet. For eksempel har pasientene med Duchennes muskeldystrofi allerede i tidlig barnealder problemer med å reise seg fra huksittende eller å gå i trapper (4).

Ved kraftige legger og svakhet i proksimal muskulatur bør man tenke på muligheten av en arvelig nevromuskulær tilstand, særskilt hos barn, men som vist her, også hos voksne.

\section{LITTERATUR:}

1. Walters J. Muscle hypertrophy and pseudohypertrophy. Pract Neurol 2017; 17:369-79.

[PubMed][CrossRef]

2. Oh J, Kim SM, Shim DS et al. Neurogenic muscle hypertrophy in type III spinal muscular atrophy. J Neurol Sci 2011;308:147-8. [PubMed][CrossRef]

3. Gowers WR. A manual of the nervous system. 2. utg. Bd. 1. Philadelphia, PA:1895.

4. Annexstad EJ, Lund-Petersen I, Rasmussen M. Duchennes muskeldystrofi. Tidsskr Nor Legeforen 2014; 134: 1361-4. [PubMed][CrossRef]

Publisert: 2. november 2020. Tidsskr Nor Legeforen. DOI: 10.4045/tidsskr.20.0505

Mottatt 6.6.2020, første revisjon innsendt 7.7.2020, godkjent 11.9.2020.

(C) Tidsskrift for Den norske legeforening 2020. Lastet ned fra tidsskriftet.no 